\title{
DAYA HAMBAT JUS APEL MANALAGI (MALUS SYLVESTRIS) TERHADAP PERTUMBUHAN BAKTERI PORPHYROMONAS GINGIVALIS SECARA IN-VITRO
}

\author{
Enda Markus Aginta Sembiring ${ }^{1}$, Yufri Aldi ${ }^{1}$, Susi $^{1}$ \\ ${ }^{\mathbf{1}}$ Fakultas Kedokteran Gigi Universitas Andalas
}

\begin{abstract}
Background: Periodontitis are one of teeth and mouth disease with prevalence is $50 \%$ of adult. Periodontitis is an inflammatory condition that cause damage to connective tissue and alveolar bone. Porphyromonas ginggivalis is one of anaerob gram-negative bacteria that cause periodontitis, these bacteria can withstand host's defenses mechanism by utilizing a virulence factor panel that cause derived innate immune and inflamatory responses. Apple Manalagi or known as apple Malang is one of the herbal plants in Indonesia. Some studies represented inhibitory effect for bacteria from its substance. Objective: The objective of this study were to determine inhibitory effect of apple manalagi (Malus sylvestris) for Porphyromonas ginggivalis. Method: Experimental laboratory. In this study Apple Manalagi will be Juiced, Juice Apple Manalagi will divide by 4 concentrate 25\%, 50\%, 75\% and 100\%. This study use diluusion method, juice apple Manalagi will aplicated to 5 samples agar MHA for 5 times. The inhibitory effect will calculated with sliding calipers, and then data will process with one way anova. Result: The result didn't show any inhibision zone in MHA to Porphyromonas ginggivalis so data analysis cann't be done. Conclusion: Apple Manalagi doesn't have inhibitory effect for Porphyromonas ginggivalis.
\end{abstract}

Keywords: apple manalagi, Porphyromonas ginggivalis, diameter inhibitory effect

Affiliasi penulis: ${ }^{1}$ Fakultas Kedokteran Gigi Universitas Andalas Korespondensi: susi, email: susi@dent.unand.ac.id

\section{PENDAHULUAN}

Penyakit periodontal banyak diderita oleh masyarakat hampir di seluruh dunia dan mencapai $50 \%$ dari jumlah populasi dewasa (Pratiwi dkk, 2015; Sari dkk,2016). Asia dan Afrika memiliki prevalensi penyakit periodontal yang tinggi dari pada Eropa dan Australia (Sari dkk, 2016). Berdasarkan survei lapangan dan studi rumah sakit di India pada tahun 2016 dilaporkan bahwa dari 31.757 orang yang diperiksa dengan rentang usia 1722 tahun ditemukan $97,51 \%$ yang berusia 18 tahun menderita penyakit periodontal. $^{1}$

Kerusakan periodontal merupakan kondisi inflamasi kronis yang ditandai dengan adanya kerusakan pada jaringan ikat dan tulang alveolar. Dari hasil penelitian pada daerah subgingiva ditemukan lebih dari 300 spesies mikroflora, mikroflora yang ditemukan pada subginggiva tidak semua menjadi penyakit. Bakteri penyebab penyakit periodontal adalah bakteri Gram negatif anaerob diantaranya Porphyromonas gingivalis, Actinomycetem comitans dan Prevotella intermedia. Porphyromonas gingivalis merupakan bakteri yang memiliki 
pertumbuhan paling cepat pada saat terjadinya penyakit periodontal. ${ }^{2}$

Porphyromonas gingivalis dapat menyebabkan penyakit periodontal karna adanya faktor virulensi. Virulensi adalah kemampuan organisme untuk menyebabkan penyakit dan mengganggu fungsi metabolisme host. Faktor virulensi yang dimiliki bakteri $P$. gingivalis diantaranya lipopolisakarida (LPS), fimbriae, kapsul dan gingipain. P. Gingivalis dapat menyebabkan peradangan dan berlanjut kepada kerusakan tulang, yang nanti akan memicu kepada tooth loss ${ }^{3}$

Perawatan untuk penyakit periodontal adalah dengan kontrol plak yang menyeluruh disertai skeling, root planning dan terapi obat antibakteri. Menurut Ardila dkk, penggunaan antibakteri yang kurang tepat dan berlebihan mengakibatkan bakteri $P$. gingivalis resisten terhadap obat antibakteri, sehingga penggunaan obat herbal dari alam menjadi salah satu alternatif dalam perawatan penyakit periodontal. Penggunaan obat herbal dari bahan alam secara umum dinilai lebih aman serta memiliki efek samping yang lebih sedikit dan memiliki banyak khasiat farmakologis, sehingga World Health Organization (WHO) menganjurkan untuk memanfaatkan obat herbal sebagai bahan alami dalam memelihara kesehatan. ${ }^{4}$
Buah Apel manalagi (Malus sylvestris) merupakan salah satu buah yang sering ditemukan di Indonesia. Buah apel kaya akan zat fitokemikal seperti flavonoid. Flavonoid yang terdapat pada apel adalah flavonol. Menurut penelitian yang menggunakan ekstrak kulit apel yang mengandung katekin didapatkan hasil memiliki aktifitas antibakteri terhadap E. coli ATCC 25922, $P$. aeruginosa ATCC 27853, dan S. aureus ATCC 29213, dan ekstrak kulit apel manalagi juga dapat menghambat pertumbuhan $S$. mutants pada kadar minimal $25 \% .^{5}$

Jus apel memiliki kadar hambat minimum (KHM) pada konsentrasi $25 \%$, tetapi jus ini tidak memiliki kadar bunuh minimum (KBM). Menurut penelitian yang dilakukan Van der Sluis, ditemukan jumlah flavonoid pada jus apel lebih sedikit jika dibandingkan dengan buah apel segar. Konsentrasi total phloridzinchlorogenic acid dan katekin justru lebih tinggi didapatkan pada ampas dibandingkan pada jus apel. Hal ini disebabkan karena sifat katekin yang sensitive terhadap proses oksidasi yang diakibatkan dari panas yang dihasilkan selama pengolahan. Menurut penelitian yang dilakukan oleh Lee, pengolahan buah apel yang menggunakan panas akan mengurangi kandungan-kandungan dalam buah apel. $^{6}$ 
Berdasarkan uraian diatas, penulis tertarik untuk melakukan uji daya hambat jus apel manalagi yang diproses dengan cold-pressed juicer terhadap pertumbuhan bakteri Porphyromonas gingivalis.

\section{METODE}

Jenis penelitian ini adalah penelitian eksperimen laboratorium dengan rancangan acak lengkap (RAL). Lokasi untuk penelitian adalah Laboraturium Mikrobiologi Fakultas Kedokteran Universitas Andalas. Penelitian dilakukan pada bulan Oktober 2017. Populasi penelitian ini adalah biakan murni bakteri Porphyromonas gingivalis. Perlakuan dihitung dengan menggunakan rumus Frederer: (t-1) (n1) $\geq 15$, di dapatkan jumlah pengulangan sebanyak 5 kali.

\section{HASIL DAN PEMBAHASAN}

Tabel 1. Zona Hambat Pada Pengujian Jus Apel

\begin{tabular}{lc}
\multicolumn{2}{c}{ Manalagi (Malus sylvestris) } \\
\hline Kelompok \\
Perlakuan & Zona Hambat \\
\hline Aquades & \\
$25 \%$ & 0 \\
$50 \%$ & 0 \\
$75 \%$ & 0 \\
$100 \%$ & 0 \\
\hline
\end{tabular}

Dari hasil tabel diatas didapatkan hasil bahwa jus apel manalagi pada konsentrasi $25 \%, 50 \%, 75 \%, 100 \%$ dan Aquades (kontrol perlakuan) tidak terdapat daya hambat terhadap pertumbuhan bakteri Porphyromonas gingivalis.
Berdasarkan hasil penelitian yang didapatkan bahwa tidak adanya zona hambat terhadap pertumbuhan bakteri Porphyromonas gingivalis, maka pengolahan dan analisis data hasil penelitian tidak bisa dilakukan.

Penelitian yang dilakukan menunjukkan hasil tidak terdapat daya hambat jus apel manalagi (Malus sylvestris) terhadap pertumbuhan bakteri Porhyromonas gingivalis. Hal ini berbeda dengan hasil penelitian yang dilakukan oleh Jannata dkk, 2014 tentang daya hambat ekstrak kulit apel manalagi pada konsentrasi 25\%, 50\% dan $100 \%$ menunjukkan hasil semakin tinggi konsentrasi yang digunakan maka semakin besar zona hambat yang didapatkan. Hasil penelitian Dewi Anggraini, 2017 yang menyatakan jus apel manalagi (Malus sylvestris) memiliki daya hambat terhadap bakteri Streptococcus mutans.

Buah apel merupakan salah satu buah yang mengalami proses Browning. Browning merupakan proses pencoklatan warna bahan pangan yang dapat disebabkan secara enzimatis maupun non-enzimatis, untuk buah apel proses browning yang terjadi adalah proses enzimatis. Browning enzimatis disebabkan adanya aktifitas enzim dari bahan pangan yang banyak mengandung substrat fenolik seperti katekin ataupun tannin. Reaksi ini terjadi bila jaringan 
tanaman dipotong, terkelupas dan karena adanya kerusakan secara mekanis yang dapat menyebabkan kerusakan integritas jaringan tanaman. Hal ini menyebabkan enzim dapat kontak dengan substrat yang biasanya merupakan komponen fenolik seperti katekin ataupun tannin sehingga substrat fenolik pada tanaman akan dihidroksilasi menjadi 3,4dihidroksifenilalanin (dopa) dan dioksidasi menjadi kuinon oleh enzim phenolase. $^{7}$

Menurut penelitian yang dilakukan oleh Yuni Indah dengan menggunakan buah naga, juga tidak ditemukan daya hambat. Salah satu yang jadi faktor adalah sifat resisten dari bakteri. Bakteri ini merupakan bakteri anaerob obligat gram negatif yang berpigmen hitam. Pigmen hitam ini dapat membantu bakteri tersebut dalam mekanisme pertahanan selnya dari efek toksik. ${ }^{8}$

Selain itu, pada penelitian yang dilakukan Dewi Anggraini pada bakteri Streptococcus mutans, tidak mengambil secara langsung hasil dari jus apel manalagi tetapi mengambil supernatannya. Pada pengerjaanya, sebelum mengaplikasikan ke kertas cakram, jus yang sudah didapatkan disentrifugasi terlebih dahulu. Sentrifugasi merupakan proses pemisahan partikel berdasarkan berat partikel tersebut terhadap densitas layangnya (bouyant density). Dari sentrifugasi akan didapatkan dua hasil yaitu supernatant dan pelet, supernatan ini merupakan substansi yang memiliki bobot jenis yang lebih rendah, dan posisinya berada di lapisan atas dan warnanya lebih jernih. Dengan mengambil supernatan dari jus apel manalagi, maka kandungan yang dipakai untuk merendam kertas cakram lebih spesifik daripada langsung merendam kertas cakram ke dalam jus apel manalagi yang menyababkan kandungan lain yang tidak dibutuhkan dalam penelitian. ${ }^{9}$

Menurut Vatai et al. (2009), menyatakan bahwa kandungan senyawa fenolik sangat sensitif, tidak stabil dan sangat rentan terhadap degradasi. Beberapa degradator yang mempengaruhi fenolik seperti temperatur, kandungan oksigen dan cahaya. Fenolik akan mengalami kerusakan dengan semakin meningkatnya suhu pengeringan, fenol juga akan meningkat seiring dengan menurunnya suhu pengeringan, karena fenol tidak mengalami penguapan. ${ }^{10}$

Kandungan fenolik yang terdapat pada jus apel manalagi (Malus sylvestris), berbeda dengan kandungan fenolik yang terdapat pada buah apel manalagi (Malus sylvestris) yang segar. Meurut penelitian yang dilakukan oleh 
Anggun Rindang Cempaka pada tahun 2013, kandungan fenolik pada buah apel manalagi yang segar berjumlah 406,57 mg/L, sedangkan pada jus apel manalagi hanya terdapat 185,22 $\mathrm{mg} / \mathrm{L}$. Dikarenakan pada proses juicing terdapat proses pemisahan sari buah dengan ampas, yang dapat mempengaruhi kadar fenolik yang terkandung dalam buah apel. Menurut Handayani dan Sulistyo, 2008, menjelaskan bahwa senyawa flavonoid belum dapat digunakan secara optimal dikarenakan senyawa flavonoid tidak stabil terhadap perubahan pengaruh oksidasi, cahaya dan perubahan kimia, sehingga ketika teroksidasi strukturnya menjadi berubah dan fungsinya sebagai bahan aktif menjadi turun. ${ }^{11}$

\section{SIMPULAN}

Dari hasil pengujian jus apel manalagi (Malus sylvestris) terhadap pertumbuhan baketri Porphyromonas gingivalis secara In-vitro dapat disimpulkan jus apel manalagi dengan pengujian difusi cakram tidak menimbulkan daya hambat terhadap pertumbuhan bakteri Porphyromonas gingivalis.

Berdasarkan penelitian yang telah dilakukan dapat disarankan hal-hal berikut:

1. Penelitian daya hambat bakteri Porphyromonas gingivalis dengan menggunakan supernatan dari jus apel manalagi (Malus sylvestris).

2. Menggunakan metode dilusi untuk menghitung daya hambat apek manalagi (Malus sylvestris) terhadap bakteri Porphyromonas gingivalis.

\section{KEPUSTAKAAN}

1. Akhilesh $\mathrm{H}$ Shewale et al. Prevalence of Periodontal Disease in the General Population of India. JJournal of Clinical and Diagnostic Research: 2016; 10.

2. Chinsembu, kazhila C. Plants and Others Natural Products Used in Management of Oral Infections and Improvement of Oral Health. Acta Tropica. 2015.

3. Pailing, A, Jimmy Posangi, P. S. Anindita. Uji Daya Hambat Ekstrak Bunga Cengkeh (Syzgyum aromaticum) Terhadap Bakteri Porphyromonas gingivalis. 2016.

4. Borutta, Annerosa, Maik Wagner. Early Childhood Carie: A Multifactored Disease. Jurnal OHDMBSC, 2010; Vol 9: 1, Maret 2010, Hal. 32-38

5. Berti, Pamela Lolita, Soetomo Nawawi, Juwita R.N. Daya antibakteri air perasaan buah lemon (Citrus limon (L.) Burm.f) Porphyromonas gingivalis dominan periodontitis (in vitro). Jurnal 
ilmiah FKG Universitas

Muhammadiyah Surakarta: 2015.

6. Blackweel, Wiley. Food

Biochemistry and Food Processing,

Second Edition. New York: 2012.

7. Ma Ma Lay, Karsani S.A, Mohajer

S, Abd Malek S.N. Phytochemical

constituents, nutritional values,

pjenolics, flavonols, flavonoids,

antioxidant and cytotoxicity studis

on Phaleria macrocarpa

(Scheff.).Boerl fruits. BMC

Complementary \& Alternative

Medicine. 2014, 14 :152.

8. Charde, M.S., Ahmed A.,\& Chakole

R. D. Apple Phytochemicals for

Human Benefits. Int. J, Pharm, Res.

Vol.1 (2) 2011: 1-8

9. Anggraini, Dewi. Jus Apel

Manalagi Menghambat

Pertumbuhan Streptococcus

Mutans Secara In-Vitro. Bali: FKG

UNUD. 2017.

10. Shofyanatul Chamidah. Daya Antibakteri Ekstrak Biji Kopi Robusta (Coffea chanepora)

Terhadap pertumbuhan

Porphyromonas

ginggivalis.Jember: Biomedik

UNEJ; 2012.

11. Chusnie, T. P. T. \& Lamb A. J. Antimicrobial Activity of Flavonoid. Int. J. Antimicrob. Agent. Vol 26 (2005) 342-356. 